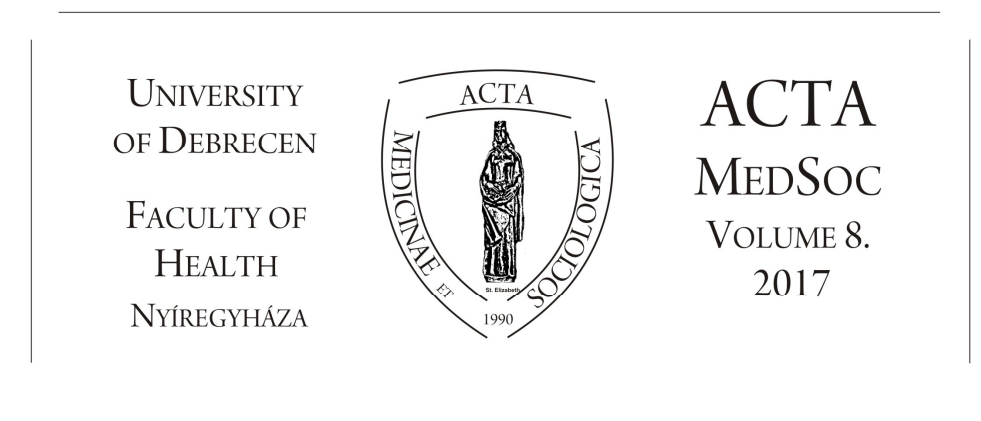

\title{
Az oktatási mobilitás helyzetképe egy határmenti térségben
}

\author{
Takács Tamara \\ Nyíregyházi Egyetem, Pedagógia és Pszichológia Intézet, \\ Szociálpedagógia Intézeti Tanszék
}

\begin{abstract}
Absztrakt. Kutatásunk az európai globalizáció kontextusában készült, mely a felsőoktatásra is hatással van. A felsőoktatás globalizálódása a Bologna folyamatban manifesztálódik, amely az oktatás egységesítését, átjárhatóságát és a hallgatói mobilitás növekedését szolgálja. Magyarországra elsősorban a határon túli magyar diákok érkeznek. Egyben ők jelentik kutatásunk adatközlőit.

Vizsgálatunkban kvalitatív mélyinterjús módszert használtunk. 46 fővel készítettünk életútinterjút a következő megoszlásban: 21 fö a Partiumi Keresztény Egyetemen (Nagyvárad), 11 fö a Babeş-Bolyai Tudományegyetemen (Kolozsvár), 14 fő a Debreceni Egyetemen folytatta tanulmányait a megkérdezés idején. A megkérdezettek között, közös kapcsolódási pontot jelent, hogy mindannyian magyar kisebbségi létbe születtek és hogy születési helyük, vagy a felsőoktatási intézményük révén kötődnek a partiumi régióhoz. A megkérdezett diákok a következő alcsoportokba sorolhatóak: azok a diákok, akik a szülöhelyükön tanulnak; azok, akik az oktatási mobilitás csatornáján keresztül az anyaország felsőoktatásában végzik teljes egyetemi képzésüket; illetve azok, akik felsőoktatási éveiket megelőzően Magyarországon telepedtek le. Jelen tanulmányban a fenti csoportok tagjait az oktatási mobilitás szempontjából vizsgáljuk és hasonlítjuk össze. Arra kerestük, hogy a választ, hogy adatközlőink tanulmányi célú mobilitása, milyen irányú és indíttatású, illetve milyen tapasztalatokkal zárul.
\end{abstract}


Kulcsszavak: oktatás, felsőoktatás, hallgatói mobilitás, vándorlás, nemzetiségi alapú hallgatói mozgás, anyanyelvü oktatás, globalizáció

\begin{abstract}
Education mobility in the border area.
Our study was made in the context of the European globalization, which has an effect on higher education, too. The globalization of the higher education is manifested in the Bologna process that serves the integration and permeability of education and the increase of students' mobility. Above all Hungarian students from abroad come to Hungary. Thus, they are the informants of our study.

Our method was qualitative interview. All in all we made 46 interviews. We have asked 21 people at the University of Partium, 11 people at the University of BabeşBolyai and 14 people at the University of Debrecen. We analysed these students by childhood history, school carrier, relationship, identity, value and future plans. Among the interviewee the common joint is that every one of them was born into a minority and they are connected to the Partium region through their birthplace or higher educational institute. Two counties of this region belong to Hungary, one belongs to Ukrain and four belong to Romania. In the future, this region, connecting three countries, could ease the professional, communicational, cultural and economical flow between countries, by the strengthening of the regional politics of the European Union.

The basic problem centres on the decision-making situations that are closely attached to the destiny of minorities. By a cross-sectional study we would like to get a broad picture of the decision of the higher educational students in connection with their studies and their own future. We would like to reveal the facts of counter attractions in this special field from the students, living in the bumper zone of world trends and minority being. The interviewees experience the effect of forces that could come from the opposite way and could influence the migration, in a different way. Thus, they explain their decisions adjusting them to their own destiny. In the empirical study, through the contentanalyze of the students' interviews, we try to find the answer to the motivation of chosing the higher education and its personality- and destiny-forming effect and the motives of the educational-based migration, and from all of these the characteristics of acting types.
\end{abstract}

Keywords: globalization, student mobility, educational-based migration, education, higher education, mother tongue education

DOI: $10.19055 / \mathrm{ams} .2017 .8 / 24 / 7$

\title{
Bevezetés
}

Jelen tanulmányban áttekintjük a nemzetközi oktatási mobilitásra vonatkozó ki és belépési adatokat, vagyis azt, hogy a diákok választása alapján, melyek a legnépszerübb célországok illetve világviszonylatban honnan érkeznek a legmobilabb hallgatók. Ezt követően áttekintjük a mobilitás feltételeit, az országok választásának mozgatórugóit, majd a fogadó és a kibocsátó országok szempont- 
rendszerét. Részletesen elemezzük a Bhandari és Blumenthal (2009) által a nemzetközi szakirodalomba bevezetett elmecsere fogalmát, mely a mobilitás sokszínüségére utal. Külön fejezetben tárgyaljuk a mobilitás hazai és romániai tendenciáit, mely kutatásuk területi vonatkozását is jelenti. A tanulmány empirikus fejezeteiben, ebben a határmenti térségben mozgó hallgatók nemzetiség alapú tanulmányi mobilitását vizsgáljuk.

Az európai uniós politikában újra fontos kérdéssé vált a hallgatók tanulmányi mobilitása. Számos ösztöndíjprogram született, amelyek hozzásegítik a diákokat a külföldi egyetemek képzéseiben való részvételhez. Lehetőségük van egy-egy szemeszter idejére belekóstolni valamelyik külföldi egyetem világába. Illetve arra is, hogy Európa, más-más országában végezzék el a BA, az MA vagy a PhD-képzést. Az 1988-as Magna Charta Universitatum, az egyetemek legfontosabb értékei közt említi a hallgatói és a tanári mobilitást. Az 1999-es Bolognai Nyilatkozat pedig már a hat alapelv közé sorolja azokat. A nemzetközi mozgás elősegítésének célja az európai elit kinevelése, a friss diplomások vonzásával tudja Európa ellensúlyozni demográfiai veszteségét (Hrubos 2011).

Cél az egységes európai munkaerőpiac létrehozása, a munkavállalói mobilitás megteremtése (Pongrácz 2011). További közvetett cél a nemzetek közeledése egymáshoz. A külföldi képzésben részt vevő hallgatók, miközben bővítik nyelvismeretüket és szakmai kompetenciájújukat, megismerhetik egy másik ország kulturális értékeit. A hazatérő diákok akár szakmai akár kulturális területen kamatoztathatják így szerzett ismereteiket. Ezzel az eszközzel az országok, nemzetek közötti ellentétek, elöítéletek is nagymértékben tompíthatóak. „Számos közvetett előnnyel számolhatunk: mint például a felsőoktatási intézmény elismertségének növekedése, képzési kínálat bővülése, fajlagos oktatási költségek csökkenése minőségre való egyidejü törekvéssel, a kapcsolati hálók bővülése. A nyilvánvaló gazdasági előnyök mellett ugyanakkor számításba kell venni a mobilitásból potenciálisan fakadó migráció társadalmi költségeit, az eltérő kulturális háttérből származó integrációs feszültségeket” (Hatos 2007:4).

A tanulmányi mobilitás oktatáspolitikai közege az Európai Unióban adott. Külön nyelvi illetve angol nyelven folyó szakmai kurzusokkal, részidejü, illetve teljes képzésekkel fogadják a külföldi országok diákjait. A külföldi képzésben való részvétel gondolata kecsegtető lehetőséget jelent a hallgatók számára, mégis csupán kisebb hányaduk vállalkozik rá. A fogadó ország nyitottsága mellett szükséges a felmerülö költségek fedezése is, melynek forrását az alacsony ösztöndíjak miatt elsősorban a család gazdasági tőkéje jelenti. Ez visszatükröződik a külföldi képzésben résztvevő hallgatók összetételében is. Az oktatási mobilitás szereplöi azok a diákok, akiknek a szülei a társadalmi hierarchián viszonylag magasan helyezkednek el. A mobilitás gyakorlati kivitelezéséhez több olyan kritérium szükséges, amellyel leginkább a magasan kvalifikált szülők gyermekei rendelkeznek. Az egyik ilyen kritérium az angol vagy a célország nyelvének 
ismerete. Fontos a jó önérvényesítő képesség, továbbá az oktatási mobilitásba való anyagi beruházás. A családok racionális döntéselmélet útján mérlegelik, hogy érdemes-e az oktatási mobilitásba beruházni. A magasabban kvalifikált szülők látják annak későbbiekben bekövetkező hasznát. A külföldi nyelvgyakorlás, a szakmai és kultúrák közötti ismeretek bővülése a későbbi előmenetel szempontjából előnyt jelenthet. Így a társadalmi egyenlőtlenségek az oktatási mobilitáson keresztül újratermelődnek. „A magasan képzett és/vagy tehetős szülők gyermekei felülreprezentáltak a mobilitásban. Az Erasmus ösztöndíjasok esetében például a támogatás csak a megélhetési költségek valamivel több, mint $40 \%$-át fedezi, a többit saját forrásból - jórészt családi segítség révén - teremtik elő az ösztöndíjasok" (Hatos 2007:4).

Ugyanakkor az oktatás expanziójával párhuzamosan az oktatási mobilitás expanziója is várható, származástól függetlenül egyre szélesebb rétegeket bevonva. Ezzel a folyamattal párhuzamba állíthatóak az országok is. A gazdaságilag fejlettebb, magas egy före jutó GDP-vel rendelkező országok nagyobb szerepet vállalnak az oktatási mobilitásban is. Ez elsősorban a diákok választásaiban jelenik meg, hiszen a fejlettebb országok a közkedvelt célországok.

A menetközi mobilitásban résztvevő hallgatók száma nagy mértékben emelkedett az új évezredben. 2010-ben világszerte a körül-belül 130 millió diákból 2,6 millió vesz részt a hallgatói mobilitásban. A diákok választásai alapján (22 százalék) az USA tekinthető legközkedveltebb célországnak. Ezt követi az Egyesült Királyság 14 százalékkal, majd Németország 10 százalékkal. Az életszínvonal mellett az angol és a német nyelvhasználat is hozzájárul a diákok vonzásához (Berács 2010).

Hasonló eredményeket találunk az egy évvel korábban megjelent nemzetközi szakirodalomban is: A mobil diákok 72 százalékát a nyolc legnépszerübb ország fogadta: Egyesült Államok (20\%), Egyesült Királyság (13\%), Németország (8\%), Franciaország (8\%), Ausztrália (7\%), Kína (7\%), Kanada (5\%) és Japán $(4 \%)$. A kibocsátást tekintve a legtöbb hallgatót a kelet-ázsiai és az európai országok küldik, ők teszik ki a mobil diákok 29 százalékát. Kína dobogós helyen áll 15 százalékkal, melyet India, Dél-Korea, Japán és Németország követ. Afrika átlag feletti eredményeket ért el ezen a téren 6 százalékkal. A legkevesebb diákot, alig fél $(0,4)$ százalékot az Amerikai Egyesült Államok küldik (Bhandari, Blumenthal 2009). 2010-ben a kibocsátás tekintve továbbra is dobogós helyen áll Kína ahol a diákok 19 százaléka vesz részt a nemzetközi mozgásban. Ezt követi India 7 illetve Korea 5 százalékos részvétellel (Derényi 2014). A legnépszerübb fogadó országok 2011-ben is tartják pozíciójukat a következő sorrendben: Egyesült Államok, Egyesült Királyság, Ausztrália, Franciaország és Németország (Kasza 2014).

Az Egyesült Államok világviszonylatban kevés hallgatót bocsát külföldi tanulmányútra. Azonban az amerikai hallgatók tanulmányi mobilitása is jelentősen 
emelkedett az utóbbi években. 1985-ben még csak hozzávetőlegesen 50000 diák, míg 2005-ben már 205983 diák vett rész a nemzetközi diákcserében. Hatvan százalékuk nyugat-európai országokat látogatott meg. Ezen belül is a leginkább preferált országok sorrendben a következők: Anglia, Olaszország, Spanyolország és Franciaország (Obst et al. 2007).

A Bologna reformok versenyképesebbé és vonzóbbá tették az európai felsőoktatást az Európán kívüli országok számára is, azonban azt megelözően is népszerű volt. Ide érkezett és érkezik világszinten a legtöbb diák (Wachter 2009). 2003-ban a 32 EURODATA országban ${ }^{1}$ 1,1 millió külföldi diák tanult. Negyvenhárom százalékuk (470.000 fö) EURODATA övezetböl, nyolc százalékuk más európai országból, míg negyvenhat százalékuk (510.000 fó) a kontinensen kívülről érkezett. Ha országonkénti bontásban nézzük, a legtöbben Kínából érkeztek $(6 \%)$, melyet sorrendben a következő országok követnek: Németország (5\%), Görögország (4\%), Franciaország (4\%), Olaszország (4\%), Törökország (3\%), Spanyolország (2\%), Lengyelország (2\%). Az EURODATA országok diákjai ugyanebben az évben föképp németországi és angliai tanulmányutakon vettek részt. Huszonegy százalékuk Németországot, tizenkilenc százalékuk Angliát, nyolc százalékuk Franciaországot, öt százalékuk Spanyolországot, tizenhárom százalékuk pedig Amerikát választotta tanulmányai helyszínéül. Érdekes hogy az EURODATA országokon kívül eső európai országokba szinte nem is mentek (Lanzendorf 2006).

A fenti adatok alapján azt mondhatjuk, hogy az Európai Unió igen sikeresen kerül ki a hallgatókért vívott nemzetközi versenyből. Továbbá hogy az európai diákok Európán belüli mozgása is igen jelentős. Tehát az Európai Unió az Európán belül és kívül történő mozgásokat tekintve egyaránt élvonalban jár. Az Európán belüli országok azonban nem egységesek, jelentős eltéréseket találunk országonként. Anglia, Franciaország és Németország fogadja a diákok kétharmadát. Belgiumban és Romániában igen alacsony a külföldi hallgatók aránya (Wachter 2009).

A demográfiai csökkenés miatt a külföldi diákok, a fogadó országok számára jelentős hallgatói bázist jelenthetnek a jövőben. Képzésük által az egyetemek sikerrel küzdenek a fennmaradásért. További előnyt jelent, hogy a fogadó ország intézményeiben képzett, és kulturálisan szocializált munkaerőre tehetnek szert.

\footnotetext{
${ }^{1}$ A tanulmány a következő országokat sorolja az EURODATA országok körébe: Ausztria, Belgium, Bulgária, Ciprus, Csehország, Dánia, Egyesült Királyság, Észtország, Finnország, Franciaország, Görögország, Hollandia, Írország, Izland, Lengyelország, Lettország, Liechtenstein Hercegség, Litvánia, Luxemburg, Magyarország, Málta, Németország, Norvégia, Olaszország, Portugália, Románia, Spanyolország, Svájc, Svédország, Szlovákia, Szlovénia, Törökország.
} 
A demográfiai csökkenés zsákutcájából kivezető utat a külföldi hallgatók felé való nyitás és a felnőttképzés jelentheti (Polónyi 2011b).

A fogadó ország szempontjából az oktatási mobilitás további haszna, hogy az odaérkező hallgatók bekapcsolódnak a fogyasztók körébe. Tandíjat fizetnek, ami a célország számára gazdasági előnyökkel jár. „Ha a rendszerszintủ hasznosulást vesszük számításba, gazdasági és emberi erőforrás gazdálkodási szempontból közvetlenül azon országok járnak jobban, ahol a fogadott hallgatók aránya magasabb, mint a külföldön tanuló hallgatóké. A közvetlen gazdasági előnyök mellett - belső fogyasztás növekedése, szolgáltatások iránti kereslet növekedése, tandíj bevételek" (Hatos 2007:4).

Sok esetben a tanulmányi mobilitás végleges letelepedéssel zárul, ebben az esetben beszélhetünk oktatási migrációról. Ez munkaerőpiaci szempontból hasznos a csökkenő születésszámmal küzdő országok számára. Így kvalifikált, fiatal munkaerő kerül be az országba. Ez a mozgás a fejletlenebb országok felől a fejlettebb országok felé irányul, és hozzájárul a célország demográfiai mutatóinak javulásához (Kovács 2004). Az oktatási mobilitáson keresztül letelepülök társadalmi beilleszkedése is könnyebb, hiszen az egyetemi évek lehetőséget kínáltak a nyelv és a kultúra alapos megismerésére, a kapcsolatháló kiépülésére, egyszóval a társadalmi beilleszkedésre. A fogadó ország ingyen jut hozzá a humán tőkéhez. A felsőoktatáson keresztüli munkaerő elszívása minimális képzési költségekkel jár.

A bevándorlási politika terén szigorú USA is engedményeket tesz, hogyha a képzett munkaerő befogadásáról van szó. Obama Befektetés Amerika jövőjébe címü írásában hangsúlyozza, hogy vízumkedvezménnyel szeretné vonzóbbá tenni Amerikát a friss diplomások, a hallgatók és az egyetemi oktatók számára (Polónyi 2011a). Ez annak köszönhető, hogy letelepedésük esetén pozitív hatások prognosztizálhatóak. Az eddigi kutatási eredmények szerint bevándorlók gyermekei nagyfokú érdeklődést mutatnak a tudományok és a technológia iránt. 2005-ben a bevándorlók amerikai születésủ gyermekeinek $50 \%$-a $\mathrm{PhD}$ végzettséget szerzett. Az amerikai középiskolákban a legjobb eredményeket elért diákok 60\%-a második generációs bevándorló. Az 1995 és 2005 között keletkezett müszaki cégek negyedét bevándorlók alapították. Főleg indiai, angliai, kínai, taiwani és japán migránsok. 450000 embernek adnak munkát, és 52 milliárd dollár összbevételre tesznek szert (Bhandari, Blumenthal 2009).

A kibocsátó ország szempontjából a mobilitás sok esetben károkat és veszteséget okoz. A gazdasági élet tekintetétében pénzmozgás kifele irányul. A diákok külföldi országokban költik el ösztöndíjukat és egyéb hazai területröl származó pénzforrásaikat. A migráció során éppen a szakképzett, fiatal, tehetséges munkaerő kerül ki. Kelet-Európa, közelebbről tekintve Magyarország is elsősorban kibocsátó országnak számít. A fiatal és képzett munkaerö-elvonás nem csupán gazdasági, hanem demográfiai hátrányokkal is jár. A magyarországi bevándorlás 
alacsony intenzitású. Magyarország nem jelent vonzerőt sem az alacsonyabb, sem a képzettebb rétegek számára (Melegh 2011).

A fenti tendenciákat figyelembe véve, felmerül az a kérdés, hogy a külföldön tanuló diákok visszatérnek-e a hazájukba? Ök rendelkeznek a külföldi országban szerzett szaktudással, nyelvtudással és kulturális ismeretekkel, így nagyobb eséllyel indulhatnak a munkakeresés útján, és gazdagítják a hazai kutatásokat. Visszatérésük esetén a kedvező hatású, gazdaságot serkentő agycseréről, míg elvándorlásuk esetén agyelszívásról beszélhetünk. Az elmecsere fogalmát Bhandari és Blumenthal (2009) vezette be a kutatói közgondolkodásba. A „, brain drain” (agyelszívás) 2 és ,, brain gain” (agy haszon, nyereség) fogalmak mentén bevezetik a „brain circulation” (elme forgalom, keringés) és „,brain exchange” (elmecsere) kifejezéseket. E fogalmak utalnak a mobilitás sokszínüségére. Számos ország erőfeszítéseket tesz azért, hogy külföldön tanult diákjait hazavonzza, annak érdekében, hogy a globális mobilitás nyertesei legyenek és részesüljenek a ,,globális tudásból”. Taiwan ezt a gazdasági és politikai reformokból adódó gyors gazdasági fejlődéssel érte el. Malaysia adómentességgel kompenzálja az alacsony jövedelmet a külföldről hazatérők esetében. Hiszen az ,elmecsere” gazdasági haszonnal és az ország nemzetközi versenyképessé tételével jár (Bhandari, Blumenthal 2009). Bár ebben a fogalomban kétségtelenül benne foglaltatik, az hogy a kimenő diákokat felváltják más, külföldről érkező hallgatók. Így a mobilitás által ténylegesen megvalósul a sokszínü „,elmecsere” és ,keringés”.

További tényező, hogy a globalizáció kontextusában a felsőoktatás piacvezérelt, ahol a termék a tudás. A profit a nemzeti és multikulturális végzettségek közti nyereség. A fejlődő országok intézményei között verseny folyik a tanárokért és a diákokért. Diákok, tanárok, intézmények, programok nemzetközi mozgását teszik lehetővé. Az oktatás a szolgáltató szektor része lett, amely nemzetközi piacra is termel, importál, exportál (Varghese 2009). A felsőoktatásban megjelenő hallgatói mozgás mindenképpen üzlet (Polónyi 2011a). A nemzetközi versenyben a küzdelem eszköze a reformpedagógiai módszerek bevezetése, az oktatás versenyképessé tétele, továbbá az állami pénzeszközök növelése, a költséghatékony oktatás megteremtése. A nemzetközi mobilitás fö kihívásai közé tartozik a külföldi hallgatók számára vonzóvá tenni a felsőoktatást, továbbá a külföldön tanuló diákokat hazahívni (Bhandari, Blumenthal 2009).

\footnotetext{
${ }^{2}$ Fordítás a szerzőtől.
} 


\section{Az oktatási mobilitás magyarországi jellemzői}

2000-ben 6987, 2010-ben pedig 8079 magyarországi hallgató tanult valamelyik külföldi intézményben. A magyar hallgatók által legközkedveltebb célországok 2000-ben: Németország, Egyesült Államok és Ausztria. 2011-ben pedig Ausztria, Németország és az Egyesült Királyság (Kasza 2014). A nemzetközi színtéren mozgó hallgatók alig több mint fél $(0,6)$ százaléka vesz részt a magyarországi felsőoktatásban (Berács 2010). 2006-ban az összes Magyarországon tanuló diák három és fél százaléka külföldi. Ez az arány beleilleszkedik az európai országok átlagánál alacsonyabb kelet-európai országok sorába. Csehországban (7\%) magasabb, míg Romániában és Szlovákiában alacsonyabb, egy-egy százaléknyi a külföldi hallgatók aránya (Kasza 2011).

A hallgatói mobilitás Polónyi (2011b) megközelítésében a következőképpen csoportosítható: rész illetve teljes képzésben tanuló diákok. Mindkét csoport esetén beszélhetünk nemzetiségi alapú hallgatómozgásról, amely alatt az anyaország illetve a volt gyarmattartó ország felé irányuló mozgást értjük. Az anyaországban továbbtanuló kisebbség számára a nyelv jelenti a fő vonzerôt és kapcsolódási pontot. Ennek következtében, mind Romániát mind Magyarországot elsősorban a határ menti kisebbségek tagjai választják, akik egy külföldi országban, mégis a saját anyanyelvükön folyó képzésben vehetnek rész. Nem kell számukra külön idegen nyelvü kurzusokat hirdetni, bekapcsolódhatnak az anyaországi oktatásba. Ez jelentős könnyebbséget jelent a fogadó egyetemeknek.

A képzés színvonala mellett a képzés nyelve is hozzájárul a célország kiválasztásához. Ebből a szempontból a határon túli magyarok számára Magyarország az egyik kiemelt célterület. A magyarországi részképzésben ,gyakorlatilag a határon túl élő magyar ifjúság" vesz részt (Berács 2009:14), ,jelenleg nincs nagy igény a külföldi hallgatók részéről magyar nyelvü képzés iránt, egyedül a határon túli magyarok jelentenek kivételt" (Hubert 2009:29).

„A legtöbb hallgató, (54\%), a szomszédos országokból származik, és gyakorlatilag a határon túl élő magyar ifjúságot jelenti, Ausztriát leszámítva. Ök termesztésen magyar nyelven tanulnak, és létszámuk tükrözi az adott országban lévő magyar ajkú kisebbség nagyságát” (Berács 2009:14). Hatos Pál így ír erről: ,a Magyarországon tanuló külföldi hallgatók aránya 2003/2004-es tanévében az összes hallgatói létszám 3,2 százalékát (mintegy 13000 hallgató) tette ki. A külföldi hallgatók közel 60 százaléka, a környező országokból érkezik és magyar nyelvü képzésekben vesz részt. Ök szinte kizárólag határon túli magyar közösségekből érkeznek" (Hatos 2007:1). Magyarországon a határmenti hallgatókat követően az orvosképzésre érkező diákok jelentik a mobilitás következő fő bázisát. Mindkét csoport jelentős része a Debreceni Egyetemen tanul (Polónyi 2011b). 
A Bologna Füzetek statisztikai adatai alapján a 2007/2008-as tanévben a magyarországi képzésben részt vevő külföldi hallgatók részaránya a következő megoszlást mutatja: a szomszédos országokból érkezik a hallgatók ötvennégy százaléka, azaz 8236 fö, a többi európai országból a hallgatók 23,8 százaléka, azaz 3579 fő, más földrészekről pedig a hallgatók 16,8 százaléka, azaz 2467 fő. A szomszédos országokból érkező hallgatók országonkénti bontása pedig a következő megoszlást mutatja. Romániából 3133 fő, Szlovákiából 2178 fö, Ukrajnából 1372 fö, Szerbiából 1310 fó érkezik hazánkba (Berács 2009:16). Jávor András szerint a Debreceni Egyetemre 2980 külföldi hallgató jár. Valamivel több mint 2000 fő angolul tanul, 7-800 fö pedig magyarul. A 2010-es jelentkezői arány a következő megoszlásokat mutatja: 136819 fő (97,5\%) magyar, 3129 fó $(2,3 \%)$ szomszédos ország, 317 fó $(0,2 \%)$ más ország. Botos Máté eredményei szerint a Pázmány Péter Katolikus Egyetemen körülbelül négy százalékra, míg Kerülö Judit szerint a Nyíregyházi Főiskolán négy-öt százalékra tehető a határon túli hallgatók aránya. Jávor felhívja a figyelmet arra, hogy számuk csökkenő tendenciát mutat a határon túli, elsősorban romániai magyar nyelvü egyetemek erösödésének következtében (Fábri 2011).

A 2009-es UNESCO jelentés szerint elsősorban az a diák tekinthető mobilnak, aki nem állampolgára annak az országnak ahol tanulmányait átmeneti jelleggel folytatja (Motivans 2009). Kérdés, hogy ezen túl az állampolgárságot igénylő határon túli magyar hallgatók miként jelennek meg a készülő statisztikai adatok közt. Hiszen igaz, hogy más országból érkeznek, de azonos állampolgársággal rendelkeznek. Amennyiben nem a földrajzi mozgás, hanem az állampolgárság a fô csoportosító elv a mobil diákok szelekciójánál, úgy a Magyarországra érkező hallgatok létszáma jelentős mértékben zsugorodni fog a közeljövőben.

A nemzetközi mozgásban résztvevők körét leszükítve kutatásunk alanyaira, a határ menti régiókból érkező diákokra, a következő két alapesettel találkozhatunk: Az egyik Magyarországon kezdi meg egyetemi éveit, és ott is fejezi be. Diplomáját valamely magyarországi egyetemen szerzi meg. A másik csoport tagjai Magyarországon ideiglenesen, egy vagy több szemeszterig vannak jelen. A kibocsátó ország valamelyik intézményének hallgatója, tanulmányait vagy az anyanyelvén, vagy az ország hivatalos nyelvén folytatja. A hallgatói mobilitást követően visszatér, és hazájában fejezi be egyetemi éveit. Diplomáját a kibocsátó ország valamely felsőoktatási intézménye állítja ki.

Amennyiben a tanulmányi mobilitás célja a letelepedés, úgy a határ menti régiókból érkező hallgatók nem rész-, hanem teljes egyetemi képzésen vesznek részt. Ebben az esetben a diploma megszerzését követően dől el, hogy oktatási mobilitásról vagy migrációról beszélhetünk. Az előbbi azt jelenti, hogy a hallgató csupán tanulmányainak idejét tölti külföldön. Azt követően hazájában illeszkedik be munkaerőpiacra és alapít családot. Az oktatási migráció esetében a tanulmányi mobilitás jelenti a migráció csatornáját. Célja a választott ország társadalmába és 
munkaerőpiacába történő beilleszkedés. Megkülönböztethetünk egy harmadik lehetőséget is, amelyben a végső letelepedés egy harmadik országban történik meg. Ezt a lehetőséget teremti meg a közös európai szellemiség, az országok oktatási rendszereinek harmonizálásával, a közös európai oktatáspolitika kialakításával. A mobil hallgatók bátrabb és merészebb életstratégiával rendelkeznek. Külföldi tanulmányútjaik során megtanulnak beilleszkedni egy új élethelyzetbe, alkalmazkodóbbakká válnak. Megjelenik esetükben a kettős kötődés, a kibocsátó és a fogadó ország iránt egyaránt elkötelezettek. Az informális csatornákon keresztült kialakult baráti kapcsolatok a későbbiekben lehetőséget jelentenek a fogadó intézmény környezetében való letelepedésre (Pusztai, Nagy 2005). Ezt a tendenciát erősíti az, hogy az anyaországban szerzett diplomát, a kibocsátó országok sok esetben nem ismerik el. Az ország hivatalos nyelvén újból állam-, illetve különbözeti vizsgát kell tenni a hazai bizottság tagjai elött.

Az anyaországba érkező diákok anyanyelve és nemzetisége megegyezik a fogadó országéval, de eltér a kibocsátó ország többségi népességétől. Az empirikus kutatásban bemutatjuk, hogy gyakran nem érzik otthonosan magukat a hallgatók a célországban. A kibocsátó országban szerveződő kisebbségi közösségek jelentik azt a társadalmi mezőt, ahol igazán otthonosan mozognak. Tehát az eredeti lakóhely társadalmába történik meg a tényleges beilleszkedés, a kisebbségi szubkultúrák csatornáin keresztül. Ugyanakkor a szomszédos országokból érkező magyar diákok oktatási mobilitása magában rejti a végleges letelepedés lehetőségét. A magyar nyelvű szakismeretek kevésbé kamatoztathatóak a kibocsátó ország munkaerőpiacán, többek között ez a tényező is hozzájárul ahhoz, hogy „tanulmányi mobilitásuk az esetek jelentős többségében bár statisztikailag pontosan nem meghatározhatóan - Magyarországra történő letelepedést is eredményez" (Hatos 2007:1).

A Magyarországon tanuló határon túli hallgatók egyharmada tervezi, hogy választott intézménye helyszínén integrálódjon a munkaerőpiacba, egy-egy tizedük szeretne hazájába visszatérni vagy egy harmadik országban letelepedni. További egyharmaduk a bizonytalanok csoportját gazdagítja. A szülőföldön továbbtanulók 36 százaléka tervezi a további helyben maradást, 8 százalékuk külföldi munkahelykeresésben gondolkodik, egynegyedük azonban bizonytalan azzal kapcsolatban, hogy hol szeretné leélni az életét (Pusztai, Nagy 2005).

\section{Romániai diákok Európában}

A fentiek alapján Magyarország szempontjából Románia tekinthető az egyik fő kibocsátó országnak. Ezért szeretnénk betekintést nyújtani Románia helyzetébe, hiszen adatközlőink többsége jelenleg is itt él. Roman, Monica és Suciu, Christina 
eredményei szerint mind Magyarországra, mind Romániába elsősorban a környező határ menti településekről érkeznek, saját kisebbségi tagjai a felsőoktatásba, cserediákként. A különböző kelet- és közép-európai országokból 9730 diák tanult Romániában. Köztük jelentős részarányt képvisel a Moldvai Köztársaságból érkező több mint 4200 diák. További hasonlóság, hogy mindkét ország esetében nagyobb a kimenő, mint a bejövő mobilitási arány (Roman, Suciu 2007).

A rendszerváltozást megelőzően a szovjet rendszer hatása érvényesült a romániai pedagógiai gyakorlatban. A leendő értelmiség vezető rétegének képzése Moszkvában történt (Ortan 2004). Ez is kifejezi, hogy az oktatási mobilitás során tanulmányi okból meglátogatott célország nagy hatást fejt ki a kibocsátó ország tudományos életére, s már a rendszerváltás illetve a globális folyamatok térnyerése előtt is meghatározó jelenségnek számított. A romániai totalitárius rendszer bukását követően Románia is beléphetett a nemzetközi színtérre. Az addig lezárt határok megnyíltak, lehetőséget teremtve a diákok földrajzi mozgásának. Ebből a szempontból nem elhanyagolható Románia csatlakozása az Európai Unióhoz. Az azt megelőzően vízumköteles ország állampolgárai ma már személyi igazolvánnyal utazhatnak a többi európai uniós országba. Diákjai számára elsődleges célországnak a nyugat-európai országok számítanak, hiszen a tengerentúlra még nem utazhatnak szabadon. Évente több száz diák és oktató vesz részt a különböző csereprogramokban (Roman, Suciu 2007). A külföldi ösztöndíjak során felmerülő költségek nagy részét a diákok szülei fizetik. Míg a magasan kvalifikált szülök megengedhetik maguknak, hogy biztosítsák gyermekeik számára a külföldi ösztöndíjprogramokban való részvétellel járó anyagi költséget, addig a hátrányos helyzetü szülők gyermekei kiszorulnak az európai mobilitási lehetőségekből (Dobre 2007).

A romániai dákok oktatási mobilitása a legtöbb esetben migrációban teljesedik ki. A célországban vállalnak munkát és telepednek le. Így a romániai cserediákprogramok tovább erősítik az agyelszívás jelenségét. A diákok által közkedvelt célországok fiatal és képzett munkaerőt vonzanak el a kelet-európai térségből. Ezt a veszteséget növeli a külföldi családalapítás által fokozódó demográfiai veszteség. A nyolcvanas éveket követően folyamatosan növekszik azoknak a romániai hallgatóknak az aránya, akik az oktatási mobilitás csatornáján keresztül Nyugat-Európába vándorolnak. Az itt élő magyar ajkú kisebbség számára Magyarország, míg a román nemzetiségü diákok számára Nyugat-Európa jelenti a fö vonzerőt. 2004-ben a romániai hallgatók 2,4 százaléka vett részt az európai mobilitási programokban, meghaladva ezzel a 2,2 százalékos európai átlagot. Legkedveltebb célországok közé tartozik Franciaország, Németország, Magyarország és Olaszország. Nem elhanyagolható részarányuk ment az Amerikai Egyesült Államokba. Az OECD adatai szerint 2004-ben, a romániai hallgatók 4474 fővel Franciaországban, 4220 fővel Németországban, 3320 fővel az Ame- 
rikai Egyesült Államokba, 3147 fővel Magyarországon és 1225 fővel Olaszországban képviseltették magukat (Roman, Suciu 2007).

Románia esetében a kimenő mobilitási arány 3,2 százalékos, amely az 1,5 százalékos bejövő mobilitási aránnyal párosulva 1,7 százalékos nettó mobilitási veszteséget eredményez. Ez a helyzet azonos a legtöbb közép- és kelet-európai országban, hiszen a fö vonzerőt Nyugat-Európa és az Egyesült Államok jelentik, ahol a nettó áramlás pozitív. Fiatal és képzett illetve képzést folytató lakosságot integrálhatnak így. A fogadó országok részesülnek a külföldiek tehetségéböl, ami Románának mint kibocsátó országnak veszteség, hiszen elvándorló fiataljai hozzáadott értéket jelenthetnének a társadalom fejlődésében (Roman, Suciu 2007).

Roman, Monica és Suciu, Christina 2004-es adatfelvétele során a romániai diákok ötvenöt százaléka úgy nyilatkozott, hogy elsősorban a jobb életszínvonalbeli kilátások miatt költözne el. Tehát az életszínvonalbeli különbségek teszik Romániát kibocsátó országgá, meghatározva ezzel a migráció fő mozgatórugóját. A megkérdezettek csupán huszonhárom százaléka nyilatkozott úgy, hogy nem szeretné elhagyni az országot, amelyben él. Az elvágyódók ötvenhárom százaléka egy nyugat-európai országban, húsz százaléka az Amerikai Egyesült Államokban szeretné leélni életét (Roman, Suciu. 2007).

A fenti adatok ellenére jelen tanulmányban bemutatott kutatás egyik fö eredménye hogy az erdélyi magyar fiatalok jelentős része a szülőföldön kíván maradni. Felmerül a kérdés, hogy vajon a kisebbségben élő magyarok jobban ragaszkodnak-e Romániához, mint a többségben élő románok? Vagy inkább arról van szó, hogy a rendszerváltozást követően az elvágyódó magyar kisebbség gyorsabban telepedhetett le az anyaországban, mint az elvágyódó románok, akiknek nyelvi és kulturális különbségekkel kell egy választott célországba érkezniük? Ez lehet az oka, hogy a mintában szereplő - hazai egyetemeken tanuló - diákok már az otthonukhoz erősebben ragaszkodóak köréből kerültek ki? A kutatás kvalitatív jellege miatt ezt nem jelenthetjük ki kategorikusan, azonban ez a jelenség mindenképpen figyelemre méltó.

\section{Empirikus eredmények}

Vizsgálatunkban kvalitatív mélyinterjús módszert használtunk. Negyvenhat fövel készítettünk életútinterjút a következő megoszlásban: huszonegy fő a Partiumi Keresztény Egyetemen (Nagyvárad), tizenegy fö a Babeş-Bolyai Tudományegyetemen (Kolozsvár), tizennégy fő a Debreceni Egyetemen folytatta tanulmányait a megkérdezés idején. A megkérdezettek között, közös kapcsolódási pontot jelent, hogy mindannyian magyar kisebbségi létbe születtek és vagy 
a születési helyük, vagy a felsőoktatási intézményük révén kötődnek a partiumi régióhoz. Jelen alfejezetben adatközlőink tanulmányi mobilitását mutatjuk be.

A Partiumi Keresztény Egyetem diákjai az adatfelvétel idején nem vehettek részt az Erasmus ösztöndíj programokban az intézmény akkreditációs problémái miatt. Így a Balassi Intézet által szervezett ösztöndíjprogramokra jelentkezhettek. Ezen keresztül a budapesti, a debreceni és a szegedi egyetemekre juthattak el. A Balassi Intézeten által felkínált ösztöndíj összege havi 41400 Forint, ami mellé kollégiumi féröhelyet is kaptak a diákok. Ez a szakmai fejlödés mellett anyagi fellendülést is jelentett számukra. A hallgatók a magyarországi egyetemen bármilyen kurzust látogathattak. Továbbá lehetőségük volt potenciális migrációjuk elsődleges célországát megtekinteni. A hallgatói mobilitás mellett az oktatói mobilitás is jelen volt, hiszen a magyarországi egyetemekről számos vendégtanár tanított a Partiumi Keresztény Egyetemen. Így a magyarországi alapítású és finanszírozású egyetemre, anyagi és tudástőke konvertálódott át a magyarországi képzőhelyekről. Az interjúalanyok véleménye megegyezett abban, hogy a magyarországi egyetemek felszereltebbek, mind a tárgyi feltételeket, mind a könyvtárállományt illetően. A képzést színvonalasnak tartották. Viszont hiányolták az otthon megszokott családias légkört. A következő interjúidézetek az ezzel kapcsolatos reflexiókat mutatják be:

„Már másodjára vagyok itt, Debrecenben, a hittudományin. Voltam egy hónapot februárban, és most két és fél hónapot nyertem. Az államvizsga dolgozat miatt jöttem, hogy azt megírjam. Könyvtár. Meg hogy vezessék, két vezetö tanár van, egy ott egy itt." [P11, turisztika, teológiaszociális munka szakos, fiú]

„Az egyetem, ami nagyon tetszett, a felszereltsége összehasonlitva az ittenivel. Látszik, hogy nem úgy lett az egész épület kialakitva, mint itt, hogy kaptak valahova egy épületet, beköltöztek, és akkor legyen egyetem, és csináljuk valahogy, ahogy megy. Látszik, hogy az tényleg egy egyetemnek lett épitve. És más a légkör is kicsit. Meg föleg a felszereltség. Minden teremben projektor, nagyobb a könyvtár. Szerintem ez szükséges a diákoknak, egész más oda járni. De nagy közösség nem volt kialakulva. Állandóan cserélödtek az emberek. ... Föként azért mentem ki, mert kellett anyag a szakdolgozathoz, teológiából." [P19, szociológia-teológia szakos, fiú]

„Megtudtam, ha megnyerem még ösztöndijat is kapok. Havi 40000 Forint, a Balassi Intézettöl. Így aminek nagyon tudok örülni, hogy 'anyumék' nem kell, hogy pénzt küldjenek nekem semmilyen formában. Nekem elég, ahogy én élek. Keveset eszek. Nem költekezek pluszba." Viszont ,ott nincs ilyen élet, mint itt. Senki nem ismer senkit kivéve a kisebb közösségeket. "[P20, reklámgrafika szakos, fiú] 
A narratívák, melyek az interjúalanyok szó szerinti idézetei, arra utalnak, hogy az anyaország egyetemein nem találták meg az otthon megszokott közösségi életet, viszont az oktatás színvonalát magasabbnak, az eszközökkel valló ellátottságot jobbnak tartották a külhoni kisebbségi egyetemnél. P11 számára a szakdolgozatírásban jelentett segítséget, P19 kiemelte a tárgyi feltételekben megjelenő különbségeket, $P 20$ számára pedig anyagi fellendülést is eredményezett a tanulmányút. A diákok tapasztalatait az oktatók is igyekeztek integrálni a képzésekbe, ami kedvezően hatott a kibocsátó intézményre:

„,Most már kialakult egy munkastílusom. Föként a gyermekillusztrációkat szeretem. Népmesés stílusban dolgozom. Budapesten a részképzésen alakult ki. ... Az oktatás jobban tetszett. Az oktatás színvonala nagyon tetszett és voltak olyan tanárok, akik pozitívan álltak hozzánk. ... Mi elmondtunk ezt a különbséget az itteni tanárainknak és most próbálják ök is behozni ezeket. Kezdenek kiállitásokat szervezni a diákok munkáiból." [P18, reklámgrafika szakos, fiú]

A megkérdezettek számára a magyarországi tanulmányutak elsődleges célja a könyvtárak felkeresése és a szakdolgozatírás volt. A hallgatók kiemelték a magyarországi képzés és felszereltség színvonalát. A különböző ösztöndíj programok által azok a diákok is bekapcsolódhattak a magyarországi képzésekbe, akik anyagi gondok, vagy lokális kötődésük miatt a romániai magyar képzések köréből választottak.

A Babeş-Bolyai Tudományegyetem az adatfelvétel idején akkreditált felsőoktatási intézmény, ezért diákjai részt vehettek az európai csereprogramokban. A megkérdezettek közül ketten Csehországba, ketten pedig Magyarországra utaztak a tanulmányi ösztöndíj keretében. A Partiumi Keresztény Egyetem diákjaival szemben, nem tartották színvonalasabbnak a magyarországi képzést, az egyetemeket hasonló színvonalon értékelték.

„Ez egy Európai Uniós ösztöndij, Erasmus. Az egyetemen meghirdették, és átlag szerint döntik el, hogy ki megy és ki nem. ... Tetszik az egyetem, hasonlit a miénkhez. Érzödik rajta, hogy ugyanolyan színvonalú. Ami nem tetszik nekem benne, hogy itt szétszórva vannak az emberek. Nálunk otthon csoportokban vagyunk. És azért megvan annak a hangulata, ha ugyanazokkal az emberekkel jársz órára. Szerintem ott jöttünk mi öszsze. ... Az elején volt olyan, hogy álltam az ablakban és néztem kifele, és azon gondolkoztam, hogy bennem most annyi erö van, hogy gyalog hazamennék. Annyira honvágyam volt és annyira hiányzott minden." [B01, informatika szakos, lány] 
B03 így emlékszik vissza pécsi ösztöndijára: „, Konkrétan rossz élményem nem volt, csak nem éreztem túl jól magam. Lehet, hogy az is közrejátszott, hogy unatkoztam. De rosszindulatú emberekkel nem találkoztam. ... Nem tüntek valami barátságosnak ott az emberek. Nálunk, aki késöbb kapcsolódik be az oktatásba, nem is lehet észrevenni, hogy késöbb jöttek. Leültetjük öket, beszélgetünk velük, és ha megyünk valahova, akkor öket is hívjuk. Mi akárhova megyünk leülünk, és megbeszéljük hol találkozunk. Amikor ott volt a gólya buli akkor vártam, hogy oda jöjjenek hozzám és megbeszéljük, de nem jött oda senki. Másnap egy csoporttársam megkérdezet, miért nem voltam a gólya bulin." [B03, informatika szakos, lány]

„, Csehországban voltam ösztöndíjjal, de nem vágyok vissza, pedig nagyon jók voltak a körülmények. " [B06, informatika szakos, fiú]

Míg a Balassi Intézet által szervezett magyarországi részképzéseken, a hallgatók kedvük szerint állíthatták össze az általuk látogatott kurzusokat, tanulmányi teljesítményükről nem kellett elszámolniuk a küldő intézmény felé. Addig az Erasmus programban részvevőknek, meghatározott számú kreditet kellett összegyüjteniük, külföldi tanulmányaik során, majd arról elszámolniuk a küldő intézmény felé. A megkérdezett diákok beszámolóiban közös, hogy a kedvező körülmények ellenére egyikük sem érezte igazán jól magát a tanulmányi ösztöndíj során. A fogadó és a küldő intézmény összehasonlítása során kiemelték, hogy hazai egyetemen szervezettebb az informális közösség, jobb közösségi hangulat uralkodik, mint a magyarországi egyetemen. Ennek ellenére a határon túli egyetemeken tanuló interjúalanyok érdeklődtek a legnagyobb mértékben a külföldi tanulmányi utak iránt, közülük is elsősorban a Partiumi Keresztény Egyetem diákjai. A magyarországi felsőoktatásban tanuló interjúalanyok a legkevésbé. Közülük csupán a magyarországi társadalomba nehezen beilleszkedö, D14 vett részt egy koppenhágai Erasmus programban, ahol nagyon jól érezte magát. A csoport többi tagja a megkérdezés idején, nem tervezte külföldi ösztöndíj programban való részvételt. Többségük nem vágyott egy harmadik országba sem ideiglenesen, sem végleges letelepedés céljából. Ezt azzal magyarázták, hogy nem szívesen vállalták volna még egyszer az új környezetbe való beilleszkedés nehézségeit. Melynek oka az, hogy mobilitásukat nem változatosság kedvelésé, hanem az anyanyelvü környezetbe való bekerülés motiválta.

„Nem vonz a külföldi részképzés. Félek is egy kicsit megint egy új helyre beilleszkedni. Mennyire éri meg az állandót valami változóért felcserélni, annyira nem szeretem a változatosságot." [D11, informatika szakos, fiú]

„,Most azt érzem, nem mennék külföldre. Utazgatni szeretek, de ha azt mondaná valaki, menjek el Angliába pár hónapra ösztöndijjal, akkor én 
azt mondanám, miért mennék el. Ennyi környezetváltás elég volt nekem, hogy most azt mondjam, itt nagyon jól vagyok, és akkor én nem akarok sehova menni. Nem is fordult meg soha a fejembe, hogy elmenjek." [D21, pedagógia-történelem szakos, lány]

A fenti véleményekkel szemben az egyetlen Magyarországon tanuló, külföldi tanulmányúton résztvevő megkérdezett a következöképp vélekedett: , Nagyon jó volt ott. A laborok is jobban felszereltek. Ott tapasztaltam meg elöször, hogy mit jelent kutatónak lenni. Ha volt egy ötletem kipróbálhattam, egyenrangú félként kezelik a diákokat. Meg más kultúra." [D14, biológia szakos, lány]

Ebbe a csoportba tartozó megkérdezettek közül $D 14$ az egyetlen, aki külföldi ösztöndíj programban való részvételéről számolt be. Koppenhágában töltött egy szemesztert. Nagyon jól érezte magát Dániában, ami összhangban volt Magyarországról való elvágyódásával. Annak ellenére, hogy viszonylag korán, középiskolás évei alatt került be a magyarországi közoktatásba, mégis ő volt az, aki a megkérdezett interjúalanyok közül a leginkább elvágyódott a megkérdezés idején.

Az interjúalanyok többsége arról számolt be, hogy hosszútávon, Magyarországon tervezik életüket. Sokan közülük ezt azzal magyarázták, hogy elég volt egy költözés, egy nagy horderejű változás, az életükben, stabilitásra vágytak. Az áttelepült interjúalanyok esetében az volt megfigyelhető, hogy a szülőhelyhez való ragaszkodás áttevődött az anyaországra. Ragaszkodtak ahhoz, hogy Magyarországon éljék le életüket. Az anyanyelven való mindennapi kommunikáció és továbbtanulás sok esetben a migráció mozgatórugója, amit az anyaországban kaptak meg. Megtapasztalták, mit jelent kisebbségben élni, egy harmadik célországban való letelepedésük újból kisebbségi léthelyzetet eredményezett volna.

Mind a szülőhelyen, mind a Magyarországon tanuló diákokra az volt a jellemző, hogy elsősorban a tanulmányaik helyszínén tervezték jövőjüket. Terveik közt nem szerepelt a migráció. A Magyarországon lakók esetében legföképp azért, mert ezáltal értelmüket vesztik a korábban meghozott migrációs áldozatok. Nem tervezték a külföldön való tanulást és munkavállalást sem ideiglenesen, sem véglegesen. A szülöföldön található egyetemek köréből választó minta alanyai szintén ragaszkodtak tanulmányaik helyszínéhez. Esetükben ez egyet jelentett a szülőföldön maradás szándékával. Kötödésük erős lokális identitásukra utalt, mely a magyarság megőrzésének vágyából és a jövőbe vetett fejlődés reményéből táplálkozott.

Összegségében a Babeş-Bolyai Tudományegyetem diákjai voltak a leginkább elégedettek saját képzésük színvonalával. Szerintük a romániai magyar nyelvü képzés követelményei magasabbak a magyarországinál. A Partiumi Keresztény Egyetem diákjai ellenben úgy gondolták a magyarországi képzés színvonalasabb a hazai képzésnél. A diákok véleménye összhangban volt az Európai Egyetemek 
Szövetségének hivatalos besorolásával. Az európai kritériumok alapján felállított rangsor szerint a Babeş-Bolyai Tudományegyetem a legjobbak közt, a Partiumi Keresztény Egyetem pedig a mezőny végén található. ${ }^{3}$ Mindkét oktatási intézmény megkérdezettjei között a magyarországi tanulmányutak örvendtek a legnagyobb népszerüségnek. A Magyarországon tanulók azonban csekély számban érdeklődtek a külföldi országok iránt.

Minden interjúalany erősen ragaszkodott a szülöföldhöz, vagy legalább a magyar földhöz és a magyarsághoz, továbbá a családhoz, barátokhoz, vagyis a társadalmi tőke is igen fontos szerepet töltött be értékrendjükben. A határon túli magyar kisebbségek számára az elsődleges célországnak Magyarország tekinthető. Többségük nem szeretne egy harmadik országba vándorolni. Az Európai Unió mobilitást elősegítő politikáját figyelembe véve, ez is egyfajta „otthon, illetve szülöföldön maradásnak” tekinthetö, hiszen leginkább az anyaországba vándorolnak, nem a gazdaságilag fejlettebb nyugat-európai országokba.

\section{Következtetések}

Jelen tanulmányban áttekintettük a hallgatói mozgások sokszínü és összetett jelenségét. A legnépszerübb célországok főként az angol nyelvü képzéseket is biztosító USA, Anglia, Franciaország és Németország. Éppen a legközkedveltebb fogadó ország, küldi a legkevesebb hallgatót a nemzetközi szintérre. Az adatokból úgy tünik a hallgatói mozgások megegyeznek a nemzetközi vándorlások mutatóival, a gazdaságilag fejletlenebb országok felöl a gazdaságilag fejlettebb országok felé tartó mozgásokat látunk. Ennek következtében a hallgatói mozgások végleges letelepedés esetén, a vándorlások humánerőforrásainak mozgásával összeadódva növelik a területi és regionális különbségeket. A humán tőke mozgása, a fiatal és magasan képzett munkaerő vándorlása, a kibocsátó országok gazdasági hátrányait, a fogadó országok előnyeit növeli.

Hazai vonatkozásban azt láthatjuk, hogy Magyarország elsősorban kibocsátó országnak tekinthető. A Magyarországra érkező hallgatók jelentős csoportját alkotja a határmenti magyar kisebbség, akiknek az anyaország jelenti az elsődleges célországot. Ezért az empirikus fejezetekben a nemzetiség alapú hallgatói mozgásokat vizsgáltuk, föként a határmenti területek magyar anyanyelvü diákjainak magyarországi felsőoktatási intézményekben való tanulását, akik a magyar nyelv ismerete miatt elöszeretettel választanak magyarországi képzőhelyet. A kutatás során arra a következtetésre jutottunk, hogy a szülöhelyen tanuló

\footnotetext{
${ }^{3} \mathrm{http}: / /$ eduline.hu/felsooktatas/2011/9/8/20110908_romania_egyetemi_rangsor Letöltés ideje: 2011. 09.08.
} 
magyarajkú diákok szívesen vesznek részt a Magyarország felé irányuló hallgató mobilitás által elérhető képzésekben. A tanulmányutak által megismerik elsődleges célországukat, szakmai tapasztalatokra tesznek szert, hozzáférnek a magyar nyelvü szakirodalmakhoz, mely a szakdolgozatírás elengedhetetlen feltétele. A szociális- és társas közegbe viszont kevésbé tudnak beilleszkedni, a rövidnek mondható tanulmányi idő alatt. Azok viszont, akik a teljes képzést Magyarországon töltik, a tanulmányi idő végére beilleszkednek az anyaországba. A szakmai, nyelvi és kapcsolati szempontok miatt, legszívesebben a tanulmányok helyén alapítanak családot és vállalnak munkát. Ez utóbbi csoport már a képzési idő alatt sem szívesen hagyja el az anyaországot, egy-egy szemeszternyi idöre sem annak érdekében, hogy egy harmadik ország képzésbe betekinthessen. A kisebbségi létből többségi létbe kerülve már nem szeretnék megtapasztalni az újból kisebbségi létet eredményező mobilitást sem ideiglenesen sem véglegesen.

\section{Felhasznált irodalom}

1. Berács József (2009): Egyetemek nemzetköziesedése és a diákmobilitás. In: Kurucz Katalin (szerk): A nemzetköziesedés folyamata a magyar felsőoktatásban. Bologna Füzetek 3. Budapest, Tempus Közalapítvány, 13-25.

2. Berács József (2010): A Magyarországon tanuló külföldi hallgatók összetétele. In: Kurucz Katalin (szerk): Bologna Füzetek 4. Mobilitás Magyarországon. Lehetöségek és teendök. A 2010. január 19-i konferencia elöadásainak összefoglalói. Budapest, Tempus Közalapítvány, 15-21.

3. Bhandari, Rajika - Blumenthal, Peggy (2009): Global Student Mobility: Moving Towards Brain Exchange. In: Bhandari, Rajika - Laughlin, Stepherd (eds): Higher Education ont the Move. New Developments in Global Mobility. Institute of International Education, New York, 1-17.

4. Derényi András (2014): A felsőoktatás nemzetköziesítése: globális pillanatkép. In: Veroszta Zsuzsanna (szerk): A mozgás tere. A magyar felsőoktatás és a nemzetközi mobilitási folyamatok. Budapest, Balassi Intézet, 11-53.

5. Dobre, Raluca (2007): Băncile au oferte sărace de credite pentru studii. (Tanulmányutak alulfinanszírozása) Compact, 4. June.

6. Fábri István (2011): Demográfiai változások és a felsőoktatási intézmények rekrutációs stratégiáinak összefüggései. Felsőoktatási Mühely, 1. 13-29.

7. Hatos Pál (2007): Nemzetközi hallgatói mobilitás: magyarországi helyzetkép. In: http://www.scholarship.hu/LinkClick.aspx?fileticket=1eAC6R7PhM\%3D\&tabid= 144\&language $=$ hu-HU (letöltés 2010. 06. 23.)

8. Hrubos Ildikó (2011): Örök felsőoktatási érték - változó hangsúlyokkal. Educatio, 2. 208-219. 
9. Hubert József (2009): Nemzetköziesedés az intézményfejlesztési tervek tükrében. In: Kurucz Katalin (szerk): A nemzetköziesedés folyamata a magyar felsőoktatásban. Bologna Füzetek 3. Budapest, Tempus Közalapítvány, 26-39.

10. Kasza Georgina (2014): A nemzetközi hallgatói mobilitás statisztikai megragadása. In: Veroszta Zsuzsanna (szerk): A mozgás tere. A magyar felsőoktatás és a nemzetközi mobilitási folyamatok. Budapest, Balassi Intézet, 53-83.

11. Kovács László (2004): Quo vadis Európa? A népességszám alakulása a XX. században és a XXI. század első felében. Magyar Tudomány, 7. sz.

12. Lanzendorf, Ute (2006): Foreign students and study abroad students. In: Kelo, Maria - Teichler, Ulrich - Wachter, Bernd (eds): EURODATA. Student mobility in European higher education. Bonn: Lemmens Verlags\& Mediengesellschaft, 7-54.

13. Melegh Attila (2011): A globalizáció és migráció Magyarországon. Educatio, 2. 166-180.

14. Motivans, Abert (2009): Global Education Digest, Compating Education Statistics Across The Word, Montreal, UNESCO Institute for Statistics.

15. Obst, Daniel - Bhandari, Rajika - Witherell, Sharon (2007): Meeting America's global education challenge: Current Trends in U.S. Study Abroad and The Impact of Strategic Diversity Initiatives. Ile study abroad white paper series. Issue Number 1.

16. Ortan, Florica (2004): Introducere în pedagogie şi ştinţele educaţiei. (Bevezetés a pedagógiába és a neveléstudományba.) Oradea, Editura Universităţii din Oradea.

17. Polónyi István (2011a): A külföldi tőke és munkaerő szerepe. Educatio, 2. 139-149.

18. Polónyi István (2011b): Keresztúton a hazai felsőoktatás. Felsőoktatási Mühely. 2011/1. 29-43.

19. Pongrácz Kornélia (2011): „És mégis mobil a föld” - Nemzetközi hallgatói mobilitás a 21. század elején. Educatio, 2. 284-286.

20. Pusztai Gabriella - Nagy Éva (2005): Tanulmányi célú mobilitás Magyarország keleti határvidékein. In: Educatio, 2. 360-384.

21. Roman, Monica - Suciu, Christina (2007): International Mobility of Romanian Students in Europe: From Statistical Evidence to Policy Measures. (Romániai diákok nemzetközi mobilitása Európában: a statisztikai tényektől a politikai elemzésekig.) The Romanian Journal of European Studies, No. 5-6. Special issue on migration.

22. Varghese, N.V. (2009): GATS and Transnational Mobility in Higher Education. In: Bhandari, Rajika - Laughlin, Stepherd (eds): Higher Education ont the Move. New Developments in Global Mobility. Institute of International Education, New York, 17-29. 
23. Wachter, Brend (2009): Increasing Europe's attractiveness for international students: What can we learn from the Bologna Process? In: Bhandari, Rajika - Laughlin, Stepherd (eds): Higher Education ont the Move. New Developments in Global Mobility. Institute of International Education, New York, 49-65.

\section{Takács Tamara}

2009-től Nyíregyházi Egyetem adjunktusa, az Alkalmazott Pedagógia és Pszichológia Intézet, Szociálpedagógia Intézeti Tanszéken. Doktori tanulmányait a Debreceni Egyetem, Bölcsészettudományi Kar, Humán Tudományok Doktori Iskola, Neveléstudományi Doktori Programjában folytatta. Értekezésének címe: Közösségi kötődés és identitás egy határmenti felsőoktatási térségben, melyet 2015-ben védett. 